\title{
Algal pigments in Baltic sediments as markers of ecosystem and climate changes
}

\author{
Grażyna Kowalewska* \\ Institute of Oceanology, Polish Academy of Sciences, Powstańców Warszawy 55, Sopot 81-712, Poland
}

\begin{abstract}
Chlorophylls and their derivatives, as well as $\beta$-carotene, were determined in recent ( 0 to $10 \mathrm{~cm}$, not older than $100 \mathrm{yr}$ ) and old (up to $600 \mathrm{~cm}$, $8000 \mathrm{yr}$ old) sediments from the Baltic Sea. The data are related to environmental conditions and historical data of exceptional meteorological events that have taken place in Poland and neighbouring countries since the 10th century. The results for recent sediments indicate that pigments are sensitive markers of primary production and of algal groups dominating the overlying water column, but also of sedimentary and postdepositional conditions, especially anoxia and hydrodynamic changes. Studies on deep sediments suggest that climatic phenomena might have had comparable or even greater influence on algal growth in the Baltic environment than present day anthropogenic input, i.e. pollution.
\end{abstract}

KEY WORDS: Algae $\cdot$ Pigments $\cdot$ Sediments $\cdot$ Baltic $\cdot$ Ecosystem $\cdot$ Climate Resale or republication not permitted without written consent of the publisher

\section{INTRODUCTION}

Eutrophication was already regarded as one of the basic problems of the Baltic Sea some time ago (HELCOM 1987). General opinion is that it is caused by elevated concentrations of nutrients in the Baltic as a result of anthropogenic input during the last 50 yr. One should not forget that nutrients may also originate from natural sources, e.g. nitrites and nitrates from atmospheric nitrogen during thunderstorms. Algal growth in the Baltic also depends strongly on climatic conditions such as air temperature, precipitation, solar radiation, winds, ice thickness and extent (HELCOM 1996).

Chlorophyll a has been used as a marker for changes of phytoplankton biomass in the marine environment for many years (e.g. Jeffrey \& Mantoura 1997). This pigment occurs in almost all plants, including unicellular and macro-algae; chlorophyll $b$ occurs in green algae and higher plants; chlorophylls $C$ occur in diatoms and dinoflagellates (Jeffrey \& Vesk 1997) and

*E-mail: kowalewska@iopan.gda.pl also in brown macroalgae (Bianchi et al. 1997); $\beta$-carotene accompanies chlorophyll $a$ in all species of algae (Jeffrey \& Vesk 1997). Pyrophaeophytin, phaeophorbides and steryl chlorins are products of grazing of different zooplankton taxa (Shuman \& Lorenzen 1975, King \& Wakeham 1996); phaeophytins and also phaeophorbides may form during decomposition of chlorophylls by abiotic factors (Louda et al. 1998). Application of more sophisticated chromatographic analytical techniques enabled the use of pigments as markers of taxa and processes in the sea that relate to algae (Jeffrey 1997). Due to analytical difficulties, pigments and their immediate derivatives (e.g. chlorins) have seldom been studied in sediments, in contrast to those in the water column (Eckardt et al. 1991, 1992, Jeffrey et al. 1997). Chlorin depth profiles in sediments have been related to palaeoproductivity in highly productive marine sites and favourable preservation conditions (Harris et al. 1996). Nevertheless, only the relevant concentrations of the sum of chlorins have been determined in marine sediments, using a spectrophotometric method (Harris et al. 1996, Rosell-Melé \& Koç 1997). 
The introductory studies of Baltic sediments by HPLC started in 1992; these indicated that pigments in sediments might be valuable environmental markers not only of average primary production in the sea but also of sedimentation rate and conditions as well as the post-depositional environment (Kowalewska 1994). The studies were continued for samples collected at $\sim 40$ different sites, for different seasons and sediment depths and concerned: chlorins (i.e. chlorophylls $a$ and $b$ and their derivatives - phaeophytin $a$, pyrophaeopy-

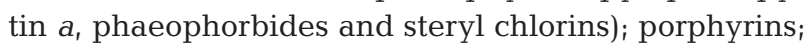
chlorophylls $c_{\text {; }}$ and, from carotenoids, $\beta$-carotene. Results for recent sediments collected before 1997 have already been published (Kowalewska et al. 1996, Kowalewska 1997).

\section{MATERIALS AND METHODS}

The analytical procedure has been described previously (Kowalewska et al. 1996, Kowalewska 1997). Sediments were collected with a core sampler or box corer and sub-sampled to different sections: in the case of recent sediments, usually to $0-1,1-5$ and $5-10 \mathrm{~cm}$; in the case of deep sediments, to $2-4 \mathrm{~cm}$ thick sections. After collection, sediments were kept frozen until analysis, i.e. not longer than 2 mo. The extraction procedure was in part similar to that used routinely in other studies of chlorins (Eckardt et al. 1991, 1992). Usually, a frozen sample (1-10 g) was left to thaw and excess water was removed by centrifugation. Samples were extracted ultrasonically with acetone, and chlorins from the acetone extract were re-extracted into benzene. Extracts were analysed by HPLC (Knauer) using 2 detectors: a diode-array (Barspec Chrom-aScope) and a fluorescence detector (Shimadzu RF 551). A Merck Lichrospher 100 RP 18e column (250 mm $\times$ $4 \mathrm{~mm}, 5 \mu \mathrm{m})$ with the same precolumn $(4 \mathrm{~mm} \times 4 \mathrm{~mm}$, $5 \mu \mathrm{m})$ was used. The mobile phase was acetone-water in a gradient system: $0 \mathrm{~min}$ 80:20, $10 \mathrm{~min}$ 85:15, $20 \mathrm{~min}$ 95:5, 40-55 $\min 100 \%$ acetone, $65 \mathrm{~min} 80: 20$, at a flow rate of $1 \mathrm{ml} \mathrm{min}^{-1}$ and for determination of chloro-

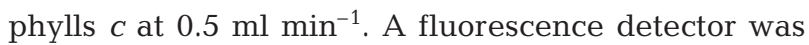
used for determination of chlorophylls C (Ex/Em 440/ $630 \mathrm{~nm}$ ) and very low concentrations of chlorins; in other cases the diode-array detector was used. Specific pigments were identified on the basis of comparison of their retention times and electronic spectra with those of standards. Standards of chlorophylls $a$ and $b$, phaeophytins $a$ and $b$, phaeophorbides and $\beta$-carotene were prepared from higher plants leaves; pyrophaeophytin a and steryl chlorins were obtained from the University of Bristol (UK) and those of chlorophylls $c$ from cultures of the diatom Cyclotella meneghiniana from the University of Gdańsk, using TLC (CAMAG, Linomat IV).
Pigments were quantified basing on their diode-array chromatograms and UV-VIS absorption spectra and, for fluorescence measurements, from calibration against diode-array chromatograms determined for the same extracts (Kowalewska 1997).

The dating of deep sediments was based on the measurement of oriented sub-samples and the comparison of variations observed in magnetic orientation (declination/inclination) and magnetic intensity with accurately dated 'master curves'. The ${ }^{14} \mathrm{C}$ dates of bulk samples and especially of the macro-fossils picked from various levels of the cores and analysed by accelerometer mass-spectrometry (AMS) were used to verify the interpretation of the palaeomagnetic data (Kotilainen et al. 1999).

\section{RESULTS AND DISCUSSION}

Selected results (sum of chlorins a) for samples collected from 1994 to 1998, averaged for the $0-10 \mathrm{~cm}$ surface layer, are shown in Fig. 1. The highest content of chlorin a was found in the most eutrophic and anoxic areas, such as the Szczecin Lagoon, which is a trap for particulate matter carried by the river Odra (the second largest river in Poland) and in the Gdańsk Deep ( 100 m water depth), which is a sink for particulates carried by the river Vistula (the largest river in Poland). These sediments contain the highest percentage of fine-grain fraction and organic carbon. The sandy sediments (e.g. open sea) contained lower amounts of organic matter and chlorins. White bars in Fig. 1 correspond to results for sediments collected before, and dark bars after, the great flood, which took place in Poland in July 1997; this particularly affected the western part of the country. For example, the observed water flow of the Odra was 6 times higher between 21 July and 20 August 1997 than in the same period of 1996. This phenomenon was accompanied by a drastic decrease of oxygen content in riverine water also carrying large quantities of organic matter (Trzosińska \& Andrulewicz 1998). After the flood, primary production was higher (Trzosińska \& Andrulewicz 1998) but intensive resuspension of sediments, which were transported from Szczecin Lagoon and settled in the Pomeranian Bay, near the mouth of the Odra, also occurred. The sediments are transported by local currents from there to the sea, to the western part of the Pomeranian Bay and also to the east towards the Bornholm Deep (P5). The particulate matter carried by the Vistula settled at first near the mouth of the river and subsequently along the usual path for transport of particular matter in this area, up to Gdańsk Deep. As a result a distinct increase of chlorin concentration was observed in sediments at the mouth of both the Odra 

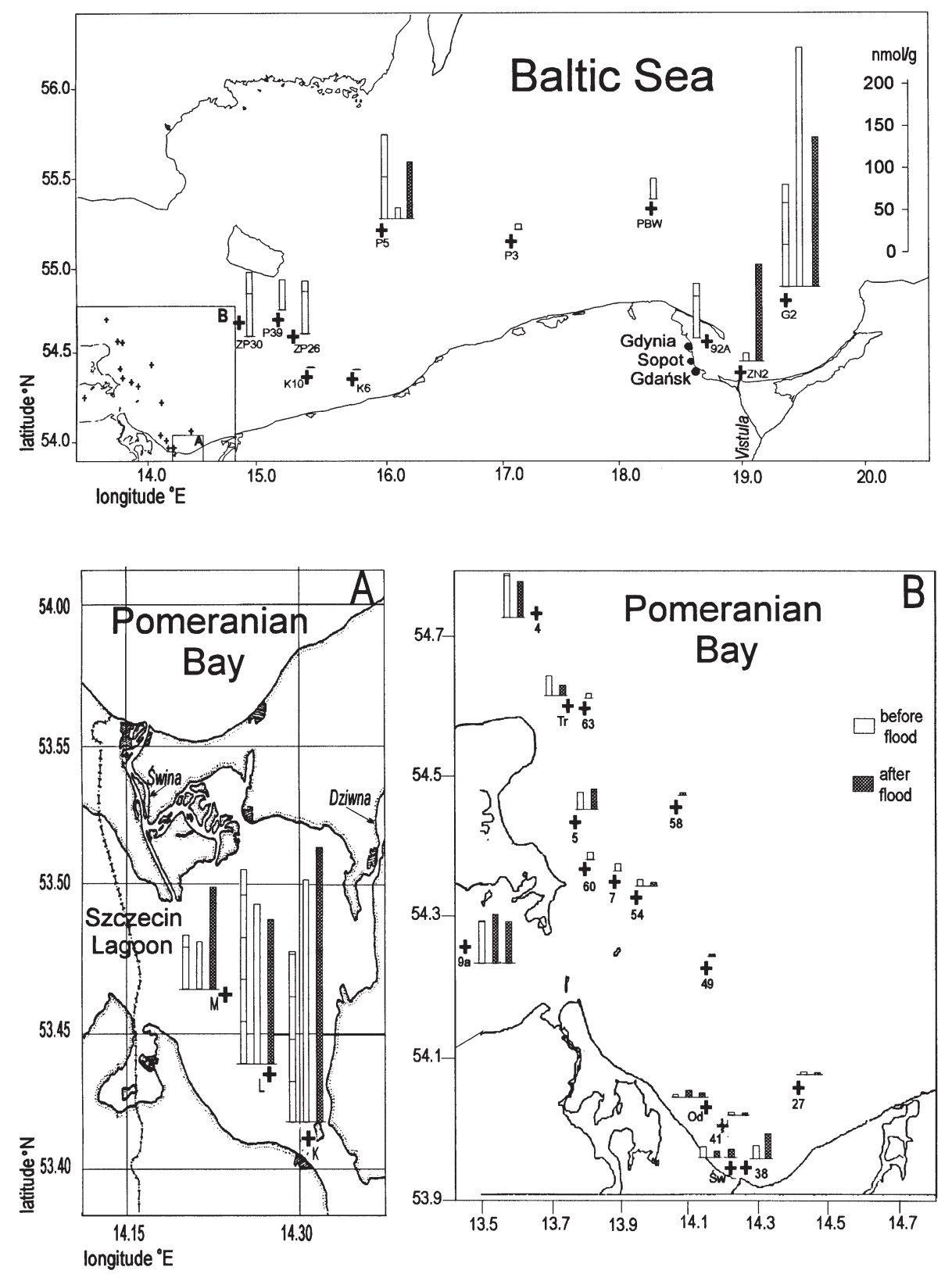

Fig. 1. Chlorins in the recent $(0-10 \mathrm{~cm})$ Baltic sediments collected in 1994-1998

and the Vistula and in the Szczecin Lagoon after the flood. In contrast, in the Deeps an increase of chlorins averaged for the surface $0-10 \mathrm{~cm}$ layer was not observed in September 1998, and the concentrations were even lower. However, the concentrations of particular pigments (e.g. chlorophyll a) were apparently higher in the surface $0-1 \mathrm{~cm}$ layer after the flood (Fig. 2). Taking into account the fact that chlorophyll $a$ is a measure of primary production, but that, similar to the majority of other pigments and their derivatives, it is decomposed by various abiotic (light, oxygen, temperature etc.) and biotic (zooplankton grazing, decom- position by microorganisms etc.) factors, its drastic concentration increase in the surface $0-1 \mathrm{~cm}$ layer (e.g. September 1998) was obviously caused by intensive algal blooms, which were observed after the flood, and favourable preservation conditions in sediments (i.e. anoxia). To confirm the last assumption, the correlation of pigments with redox potential $\left(E_{\mathrm{h}}\right)$ in sediments was checked for samples collected in the Pomeranian Bay in April 1998. For chlorophylls $a$ and $b$ this correlation coefficient was $>0.8$. This means that chlorins are better preserved in more anoxic conditions. Chlorophyll $a_{\text {, }}$ $b$ and $c$ ratios varied depending on the location of sam- 


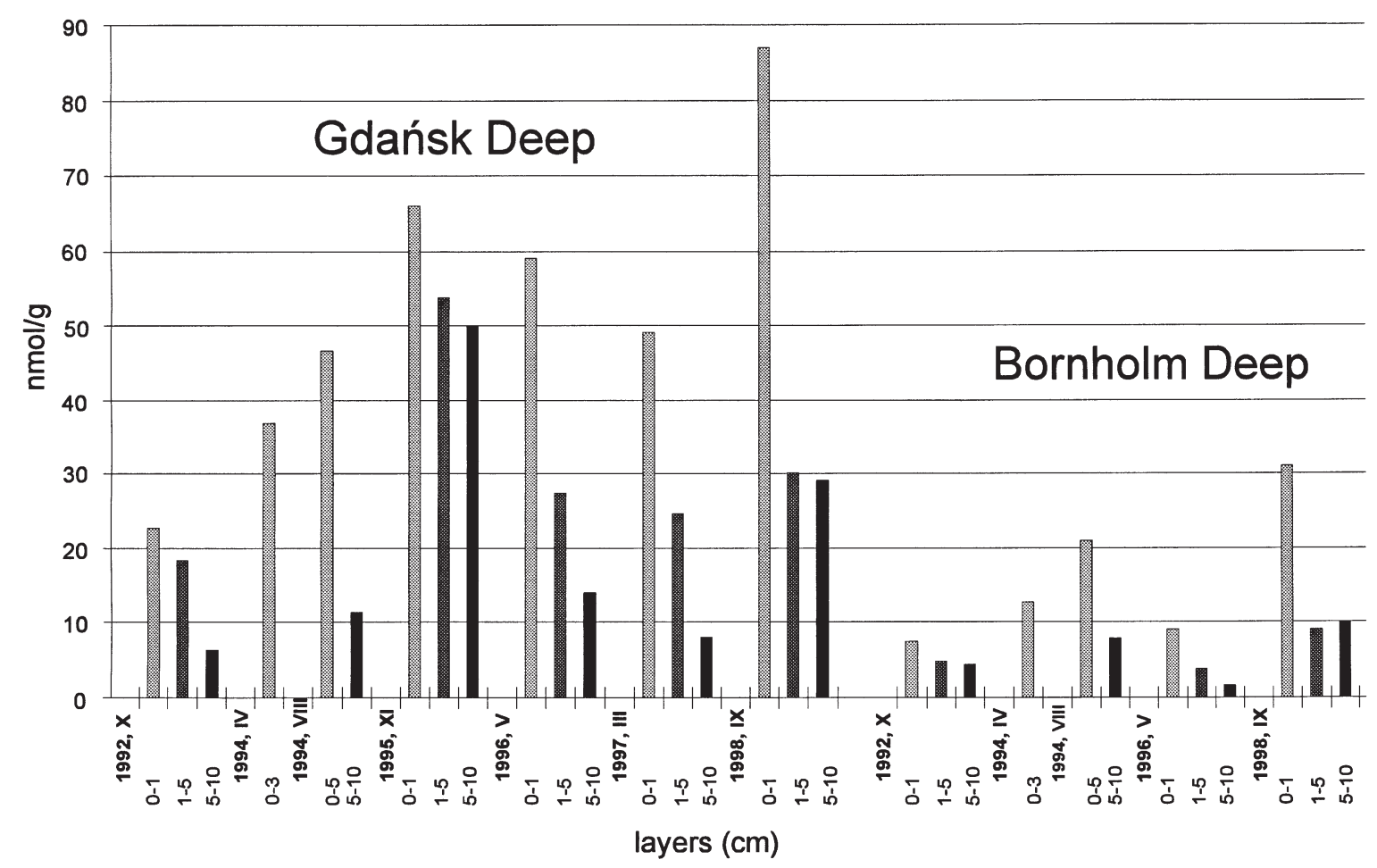

Fig. 2. Chlorophyll a in recent sediments of the Baltic Deeps (G2, P5), collected in 1992-1998

pling stations. What is most interesting is that the sediments at coastal stations contained more chlorophyll $b$ than those at open sea stations. The concentrations of

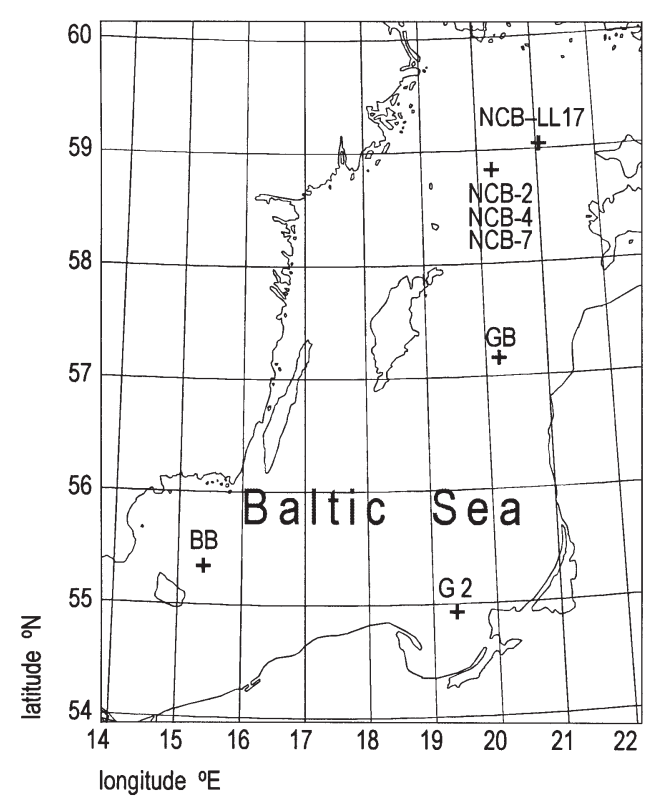

Fig. 3. Location of sampling sites for collection of old Baltic sediments (BB, Bornholm Basin; GB, Gotland Deep; NCB, North Central Basin) and for comparison-recent sediments in the Gdańsk Deep (G2), in 1996-1997 chlorophylls c correlated with salinity and were higher in the open sea than near the shore and higher in the Pomeranian Bay than in the Gulf of Gdańsk. This makes chlorophylls $c$ the indicator of marine waters and chlorophyll $b$ of fresh waters for the Baltic environment (Kowalewska et al. 1996). In conclusion, one may say that the content and composition of algal pigments in sediments depend first of all on primary production in the overlying waters but also on hydrodynamic and favourable sedimentary and postdepositional conditions, especially anoxia.

Old Baltic sediments were collected at different sites in the Baltic, from up to $6 \mathrm{~m}$ under the bottom, in the Bornholm Basin, the Gotland Deep - the deepest area in the Baltic ( 400 m) and, at present, a usually anoxic area - and the North Central Basin (Fig. 3). The pigments in all the samples from the cores up to $6 \mathrm{~m}$ depth (up to $8000 \mathrm{yr}$ old) were the same as those in recent (0-10 cm, not older than 50-100 yr) sediments of the Baltic, only they occurred in different proportions. Their concentrations did not change uniformly with depth, but there were sharp, irregular maxima and minima in the depth profile. There were also distinct differences in concentrations of pigments determined for samples from the 3 areas studied. The highest values of chlorins a were in sediments from the Gotland Deep (mean 50-150 nmol g ${ }^{-1}$, max. $\sim 460 \mathrm{nmol} \mathrm{g}^{-1}$ ); concentrations were much lower in sediments from the 
North Central Basin (mean 10-20 nmol g ${ }^{-1}$, max. 170 $\mathrm{nmol} \mathrm{^{-1 }}$ ) and were lowest in sediments from the Bornholm Basin ( 40 nmol g ${ }^{-1}$ for $65-255 \mathrm{~cm} \sim 1 \mathrm{nmol} \mathrm{g}^{-1}$ for $\sim 360-650 \mathrm{~cm})$. All these differences obviously result from varying primary production but also, especially for those between different sampling sites, from sedimentation and post-depositional conditions, which may be confirmed by the lithological description (Larsen \& Repecka 1997). In this report anoxia is ascribed to formation of laminated structure, and oxic conditions (bioturbation) to homogeneous segments of a core. According to this classification there were more oxic conditions and most intensive mixing at the Bornholm Deep than in the northern regions of the Baltic; there was steady sedimentation and minimum bottom transport at the North Central Basin, and the Gotland Basin experienced mostly anoxic conditions and very weak bioturbation.

There was still intact chlorophyll $a$ in deep sediment layers: for the Bornholm Deep up to $\sim 400 \mathrm{~cm}$, in the Gotland Basin up to $445 \mathrm{~cm}$, in the North Central Basin still at $330 \mathrm{~cm}$ (Fig. 4). This border is attributed to transformation of the freshwater Ancylus Lake into the Litorina Sea (Winterhalter 1992) and at each of the sites, chlorin abundance at depth obviously also depends on average temperatures in the past. The sediments most rich in chlorophyll a were those from the Gotland Deep (up to $52 \mathrm{nmol} \mathrm{g}^{-1}$ ), and had a value comparable with those in the surface $0-1 \mathrm{~cm}$ layer sediments of the Gdańsk Deep.

The concentration of chlorins in the Gotland Deep core correlates very well with organic carbon (for sum of chlorins $a, r>0.9$, exponential model), similarly to observations for the recent sediments. This proves that the majority of the organic matter in such sediments originates from plants and, judging from high amounts of undecomposed chlorophyll $a$, from marine algae. Such a conclusion is confirmed by analysis of other lipid markers in the same cores, such as sterols, terpenes and their derivatives (Winterhalter 1999). Chlorophylls $b$ and $c$ are good examples to illustrate possibilities given by analysis of particular pigments other than chlorophyll a (Fig. 5). As mentioned in the Introduction, chlorophyll $b$ accompanies chlorophyll $a$ in green algae, which are abundant in fresh or brackish waters; chlorophylls $c$ occur mainly in diatoms and dinoflagellates, which are most abundant in marine waters and prefer low temperatures. From these chlorophyll profiles we may judge that the layers between 62 and $122 \mathrm{~cm}$ for the Gotland sediments were formed under very drastically changing environmental conditions, especially in terms of salinity and temperature (Fig. 5). We may assume that there was an increase in salinity when 78-82, 98-102 and 278-282 cm deep layers were formed, as blooms of diatoms or dinoflagellates occurred. Formation of the layer at a

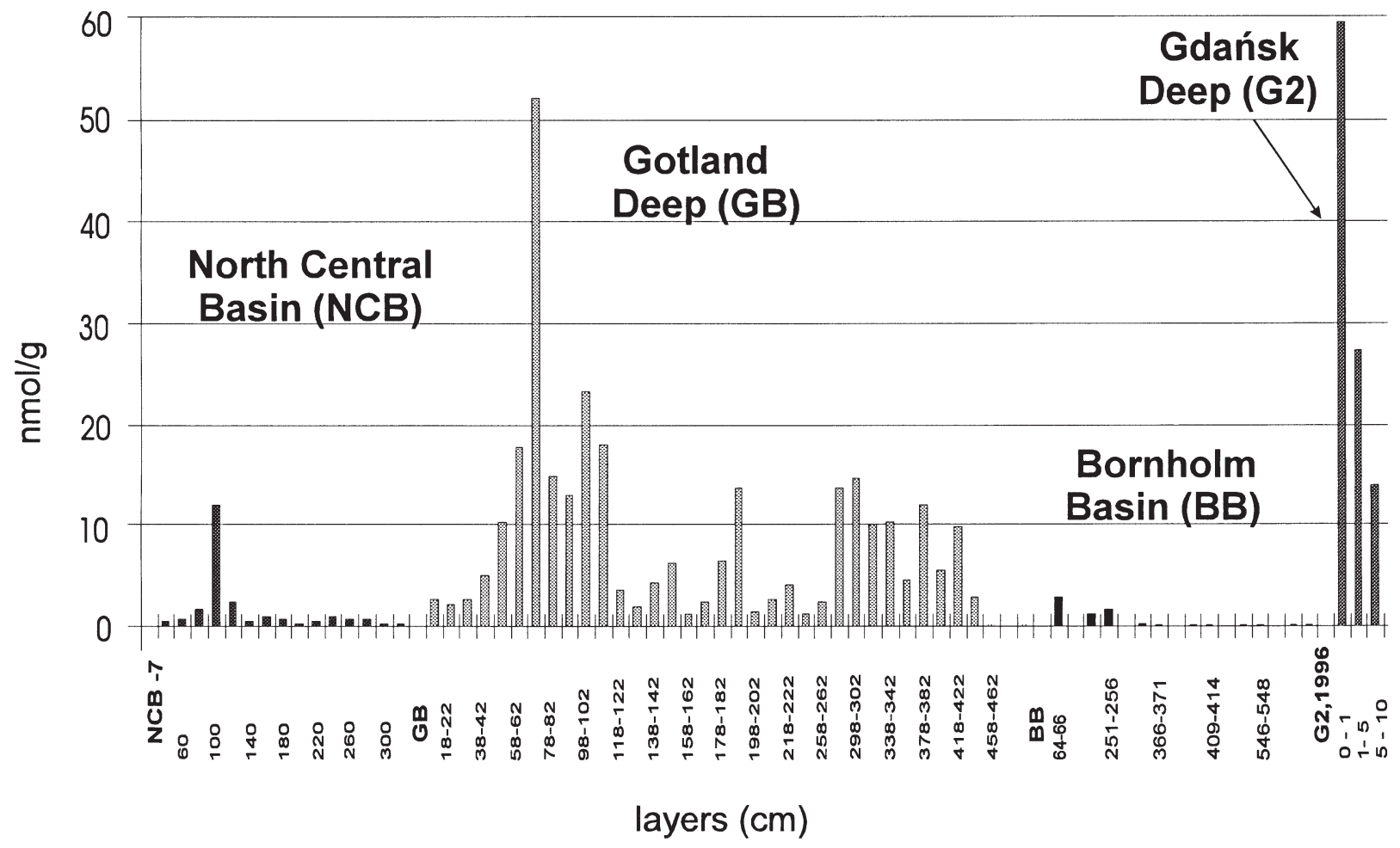

Fig. 4. Chlorophyll $a$ in old Baltic sediments and in recent sediments of the Gulf of Gdańsk 


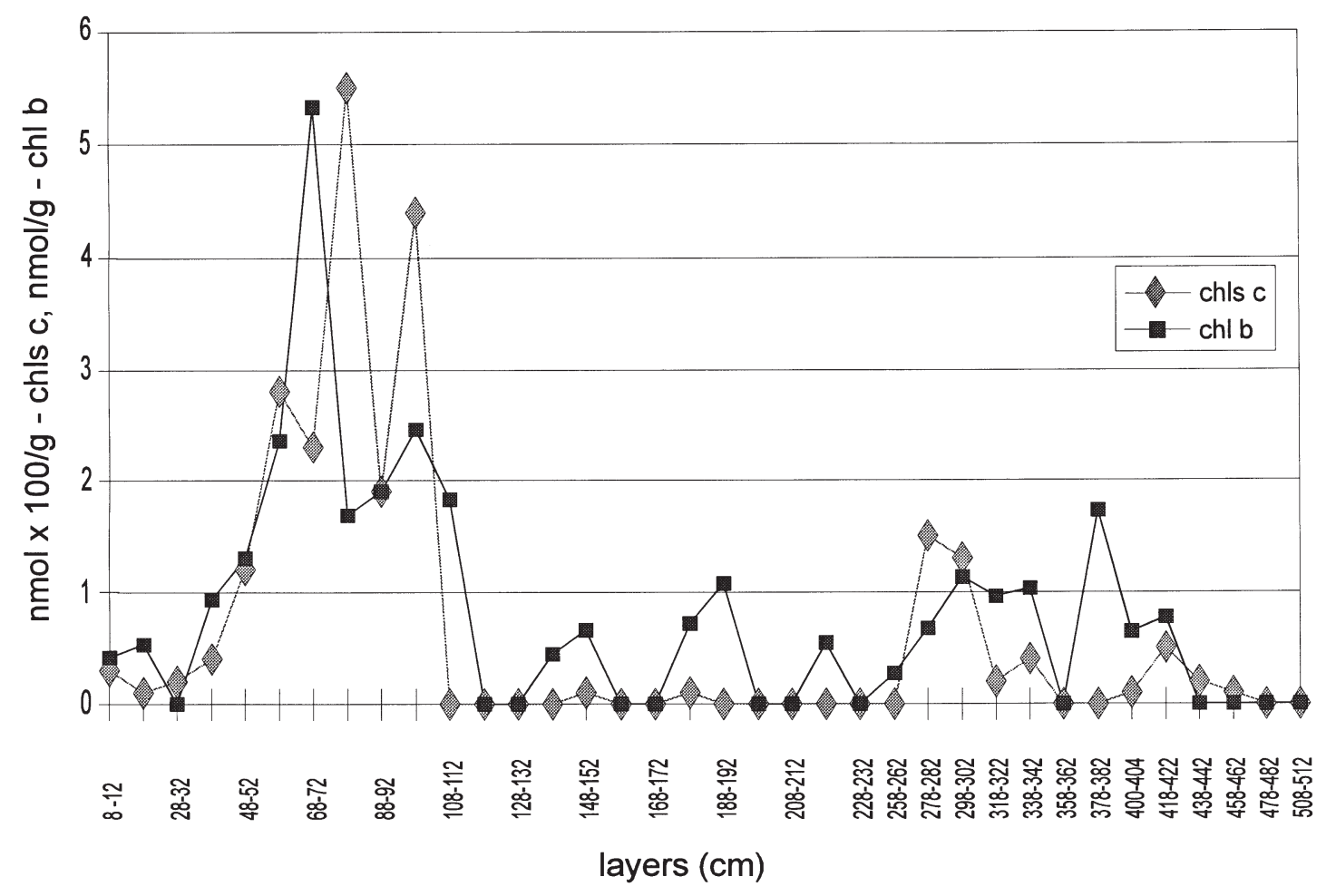

Fig. 5. Chlorophylls $b$ and $c$ in the Gotland Deep core

depth of $68-72 \mathrm{~cm}$ might correspond to a decrease of salinity and blooms of green algae. Layers 148-152, 188-192, 318-342 and 378-404 cm were most probably formed under more freshwater conditions and with a considerable percentage of green algae in the plant population. Concentrations of both chlorophylls $b$ and $c$ are much lower than those of chlorophyll $a$. This might be due to lower stability of these compounds but also to the occurrence of blue-green algae. In recent Baltic sediments, concentration of $\beta$-carotene usually correlates very well with fresh algal sedimenting material. The $\beta$-carotene and chlorophyll a profiles in the Gotland Deep core are also very similar (Kowalewska et al. 1999a), which together with low concentrations of chlorophylls $b$ and $c$ indicates that during formation of these sediments the majority of the algal population in the environment consisted of bluegreen algae with admixture of green algae, and especially during formation of sediments between 78-82, 98-102 cm and below $260 \mathrm{~cm}$, with addition of diatoms or dinoflagellates. The conclusion concerning abundance of blue-green algae in these old sediments was confirmed by analyses of molybdenum and isotopic nitrogen studies (Winterhalter 1999).

To elucidate the causes of the maximum in the chlorin profile occurring at the depth of $70-100 \mathrm{~cm}$ in the Gotland Deep core and in the North Central Basin cores, a diagram was elaborated on the basis of histor- ical chronicle quotations (Girgu's \& Strupczewski 1965) of exceptional meteorological events at the Polish coast in particular, but also at the Baltic coast of neighbouring countries. Each kind of meteorological phenomena, which could promote primary production in the Baltic and favour preservation of pigments in sediments, such as floods, river overflows (Odra and Vistula), rains, severe winters etc., was given points in the scale from 0 to 4 (i.e. none, weak, average, strong, very strong). Fig. 6 is a diagram of the sum of all the points from the 10th to 16th centuries compared to the age of sediments determined by palaeomagnetic methods (Kotilainen et al. 1999) and lithological description of the core (Larsen \& Repecka 1997, Kowalewska et al. 1999b). Accepting a certain amount of subjectivity in both the historical data and in the transfer of descriptive events to a numerical scale, it is still possible to draw some conclusions from these data. Firstly, the most intensive exceptional events relate to the laminar sequences, i.e. those formed under anoxia; periods of more calm weather apply to the homogeneous layers. For example, exceptional meteorological events were more intensive between the 14th and 15th centuries than from the 12 th to 14 th centuries. This is in accordance with higher sedimentation rate and anoxia (i.e. laminar structure) in sediments, as well as pigment maxima, and implies that not only exchange of waters with the North Sea but also wet precipitation, severe 


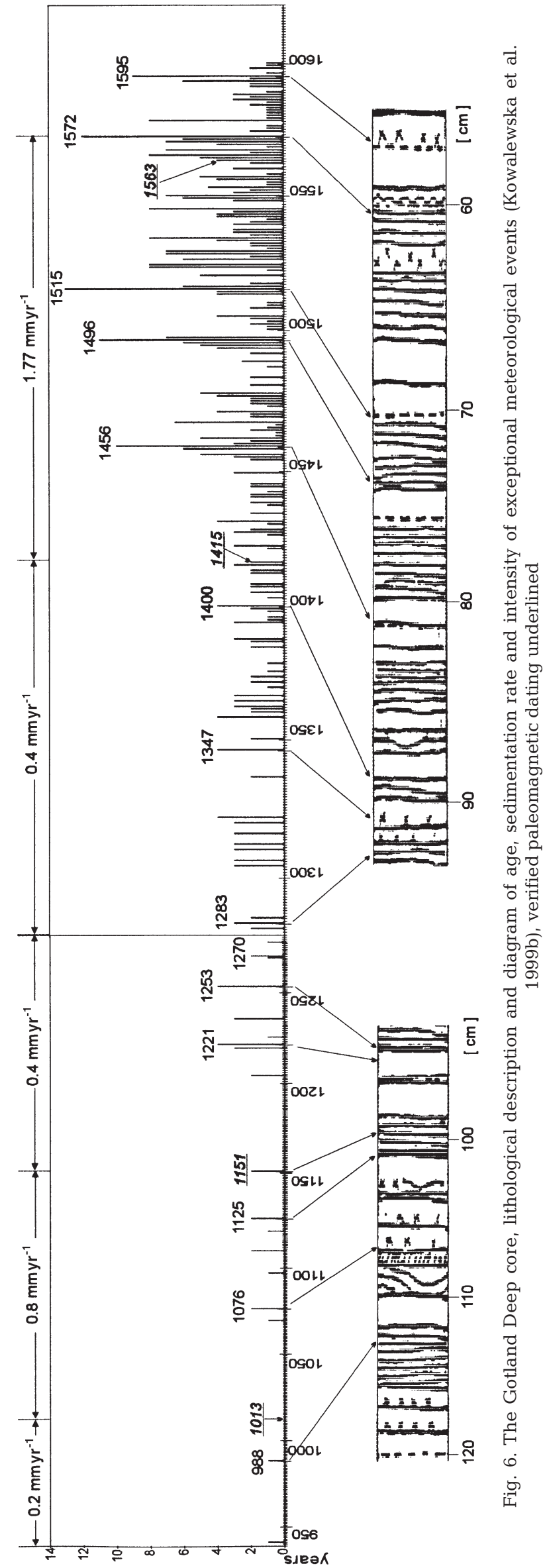

winters and rivers caused growth of algae in the Baltic Sea during those times, with the same or even greater intensity than the catastrophic blooms of the present day.

In summary, one may say that climatic phenomena might have a greater or comparable effect on algal growth in the Baltic environment than present day anthropogenic input (i.e. pollution). The question is still open about man's indirect influence on algal blooms through climate change.

Acknowledgements. This work was partly based on results of EU MAST III - BASYS (MAST programme: MAS3-CT96-0058 and the INCO programme IC20-CT-0080) in cooperation with Geological Survey of Finland, coordinator Dr Boris Winterhalter.

\section{LITERATURE CITED}

Bianchi TS, Kautsky L, Argyrou M (1997) Dominant chlorophylls and carotenoids in macroalgae of the Baltic Sea (Baltic Proper): their use as potential biomarkers. Sarsia 82:55-62

Eckhardt CB, Keely BJ, Maxwell JR (1991) Identification of chlorophyll transformation products in lake sediments by combined liquid-chromatography-mass spectrometry. J Chromatogr 557:271-288

Eckhardt CB, Pearce GF, Keely BJ, Kowalewska G, Jaffé R, Maxwell JR (1992) A widespread chlorophyll transformation pathway in the aquatic environment. Org Geochem 19:217-227

Girguś R, Strupczewski W (1965) Wyjątki ze źródeł historycznych o nadzwyczajnych zjawiskach hydrologicznometeorologicznych na ziemiach polskich w wiekach od $\mathrm{X}$ do XVI, Wydawnictwa Komunikacji i Łączności, Warszawa

Harris PG, Zhao M, Rosell-Melé A, Tiedemann R, Sarnthein M, Maxwell JR (1996) Chlorin accumulation rate as a proxy for Quaternary marine primary production. Nature 383:63-65

HELCOM (1987) First periodic assessment of the state of the marine environment of the Baltic Sea area, 1980-1985 background document. Baltic Sea Environ Proc 17(B): $82-215$

HELCOM (1996) Third periodic assessment of the state of the marine environment of the Baltic Sea, 1989-1993; background document. Baltic Sea Environ Proc 64(B):230

Jeffrey SW (1997) Application of pigment methods to oceanography. In: Jeffrey SW, Mantoura RFC, Wright SW (eds) Phytoplankton pigments in oceanography. SCORUNESCO, Paris, p 127-166

Jeffrey SW, Mantoura RFC (1997) Development of pigment methods for oceanography: SCOR sponsored working groups and objectives. In: Jeffrey SW, Mantoura RFC, Wright SW (eds) Phytoplankton pigments in oceanography. SCOR-UNESCO, Paris, p 19-36

Jeffrey SW, Vesk M (1997) Introduction to marine phytoplankton and their pigment signatures. In: Jeffrey SW, Mantoura RFC, Wright SW (eds) Phytoplankton pigments in oceanography. SCOR-UNECSO, Paris, p 37-84

Jeffrey SW, Llewellyn CA, Barlow RG, Mantoura RFC (1997) Pigment processes in the sea: a selected bibliography. In: Jeffrey SW Mantoura RFC, Wright SW (eds) Phyto- 
plankton pigments in oceanography. SCOR-UNESCO, Paris, p 167-178

King LL, Wakeham SG (1996) Phorbin steryl ester formation by macrozooplankton in the Sargasso Sea. Org Geochem 24:581-585

Kotilainen AT, Saarinen T, Winterhalter B (1999) High-resolution paleomagnetic dating of sediments deposited in the central Baltic Sea during the last 3000 years. Mar Geol 166:51-64

Kowalewska G (1994) Occurrence of chlorins in recent sediments of the southern Baltic Sea. Pol Arch Hydrobiol 41: 237-249

Kowalewska G (1997) Chlorophyll and its derivatives in recent sediments of the southern Baltic Sea collected in the years 1992-1996. Oceanologia 39:413-432

Kowalewska G, Witkowski A, Toma B (1996) Chlorophylls c in bottom sediments as markers of diatom biomass in the southern Baltic Sea. Oceanologia 38:227-249

Kowalewska G, Winterhalter B, Talbot HM, Maxwell JR, Konat J (1999a) Chlorins in sediments of the Gotland Deep (Baltic Sea). Oceanologia 41:81-97

Kowalewska G, Winterhalter B, Dobrowolska S, Kotilainen A, Konat J (1999b) Distribution and possible origin of tetrapyrroles in dated Baltic Sea sediments. Proceedings of the Third BASYS Annual Science Conference, 20-22

Submitted: September 30, 1999; Accepted: April 3, 2001
September 1999. IOW, Warnemünde, p 75

Larsen B, Repecka M (1997) Lithology/sediment description/stratigraphy in BB,GB,NCB. In: Harff J, Winterhalter B (eds) Cruise Report RV 'Petr Kottsov', 22 July to 01 August 1997. Research for BASYS. IOW, Warnemünde, p 18-38

Louda JW, Li J, Liu L, Winfree MN, Baker EW (1998) Chlorophyll-a degradation during cellular senescence and death. Org Geochem 29:1233-1251

Rosell-Melé A, Koç N (1997) Paleoclimatic significance of the stratigrafic occurrence of photosynthetic biomarker pigments in the Nordic seas. Geology 25:49-52

Shuman FR, Lorenzen CJ (1975) Quantitative degradation of chlorophyll by a marine herbivore. Limnol Oceanogr 20: 580-586

Trzosińska A, Andrulewicz E (1998) Short-term effects of 1997 flood on the marine environment of the Gulf of Gdansk and Pomeranian Bay. MIR Gdynia 1998:9-76

Winterhalter B (1992) Late-Quaternary stratigraphy of the Baltic Sea sediments - a review. Bull Geol Soc Finland 64: 189-194

Winterhalter B (1999) The state of the past, present and future Baltic Sea, based on the results of BASYS-7-Paleo-environmental studies. BASYS final report. IOW, Warnemünde

Proofs received from author(s): July 3, 2001 